\title{
A Review of Society's Behaviour Towards Land Management of Susceptible Area to Landslide in Pekuncen, Banyumas
}

\author{
Suwarno $^{1, *}$, Junun Sartohadi ${ }^{2}$,Sunarto ${ }^{2,}$ Djarot Sadharto ${ }^{2}$ \\ 1) Program of Geography Education, Universitas Muhammadiyah Purwokerto \\ ${ }^{2)}$ Faculty of Geography, Universitas Gadjah Mada \\ "Corresponding author (email: pemangkulongsor@yahoo.co.id)
}

\begin{abstract}
Land management is a manifestation of the society's behaviour in utilizing the land. The objective of the research was to examine the effect of education level, income, land tenure, knowledge, and information input on the society's behaviour in managing the area susceptible to landslide in Pekuncen sub-district, Banyumas district. The method of this research was survey by employing questionnaire to collect field data. The variable comprised of the data of education level, income, land tenure, knowledge, and information input.. Stratified random sampling was applied to determine the samples of the research. The area susceptibility class was considered as the strata in which each stratum consisted of 40 family heads as the respondents. The data analysis applied statistical test of multi-regression. Research area was divided into three classes of landslide susceptibility comprising of low, medium, and high class. Education level, income, land tenure, knowledge, and information input significantly influenced the society's behaviour dealing with land management (determination co-efficiency $\left(\mathrm{R}^{2}\right)$ was $69.9 \%$ ). It occurred in the area of medium susceptibility class. Information input (regression coefficient/(beta) $=0.817$ ) was the most influential predictor of society's behaviour in land management located in the low susceptibility class. From this research, it was expected that the description about the factors that influenced the society's behaviour in managing the landslide-prone area would be a valuable reference in preventing landslide in those areas.
\end{abstract}

Keywords: behaviour, land management, landslide, susceptibility.

\begin{abstract}
Abstrak
Pengelolaan lahan merupakan wujud dari perilaku masyarakat dalam pemenfaatan lahan. Tujuan penelitian ini untuk mengkaji pengaruh tingkat pendidikan, pendapatan, kepemilikan lahan, pengetahuan, dan penerimaan informasi terhadap perilaku masyarakat dalam pengelolaan lahan rawan longsorlahan di Kecamatan Pekuncen Kabupaten Banyumas. Metode yang digunakan adalah survei dengan menggunakan kuesioner sebagai alat untuk pengumpul data. Data yang dikumpulkan terdiri atas tingkat pendidikan, pendapatan, kepemilikan lahan, pengetahuan, dan penerimaan informasi terhadap perilaku masyarakat dalam pengelolaan lahan rawan longsorlahan. Teknik pengambilan sampel menggunakan stratified random sampling. Kelas kerawanan longsorlahan sebagai stratanya, pada tiap strata diambil 40 KK sebagai responden. Analisis data menggunakan uji statistik regresi ganda. Daerah penelitian terbagi atas tiga kelas kerawanan longsorlahan yaitu kelas rendah, sedang, dan tinggi. Tingkat pendidikan, pendapatan, kepemilikan lahan, pengetahuan, dan penerimaan informasi secara bersama-sama berpengaruh kuat terhadap perilaku masyarakat dalam pengelolaan lahan (koefisien determinasi sebesar $\left(R^{2}\right)=69,9 \%$ ) terdapat pada kelas kerawanan sedang. Penerimaan informasi (koefisien regresi/(beta) $=0,817$ ) adalah prediktor terbesar pengaruhnya terhadap perilaku masyarakat dalam pengelolaan lahan terdapat pada kelas kerawanan rendah. Dari penelitian ini, diharapkan diperoleh suatu gambaran dari faktor-faktor yang mempengaruhi perilaku masyarakat dalam pengelolaan lahan rawan longsorlahan. Hal ini tentu saja akan menjadi referensi yang bermanfaat dalam menanggulangi longsor lahan di daerah rawan longsor.
\end{abstract}

Kata kunci: perilaku, pengelolaan lahan, kerawanan longsorlahan.

\section{Introduction}

Land management covers the human's efforts to use certain land to fulfil their needs. These efforts lead to direct and indirect form of land management. The direct activity is in the form of land use planning while indirect activity is the provided information dealing with land (Stubbs and Jeffry, 1996). Land management serves to guarantee the land tenure, land value, land use and land development. Land 
management covered planning and control of land use and natural resources (Enemark, 2007). The objective of land use is to optimize the numbers of land benefits, provide benefits for land users, guarantee the sustainability of land as a resource, and regulate the determined borders (Tejoyuwono, 1990). The planning of sustainable land management should be adjusted to the land characteristics.

Land management of Pekuncen sub-district varies in some ways. These variations are in the form of: 1) terracing on slope for dry farming of seasonal plantation, 2) cutting the slope for cement- constructed housing, 3) pool making and 4) applying a farming system through terracing farming system on wet land. The implementation of wet-land farming system on the terraced-farm land is aimed to store water for preserving rice plantation. This water inundation system during rice planting season is to accelerate soil saturation. These variations on land management are the manifestation of society's behaviour in harnessing their land.

Society's behaviour is affected by numbers of complex and inter-correlated factors. These behaviours are manifested through experiences which result in certain output of individual's response towards other individuals, objects, and circumstances (James, et al., 1996). The behaviours of certain individuals determine their actions in the society. People's current behaviours also predicate their future actions and strengthen their belief through social pressures. The pressures include family economic condition, susceptibility to disaster, age, the lack of knowledge, compulsion, and beliefs (Stephen and Timothy, 2008). The lack of knowledge can be overcome by communication process. This process serves to provide knowledge and to change behaviour and actions (Mulyana, 2008). Krech, et al. (1972) stated that cognition consisting of individual's knowledge towards certain objects determine individual's behaviour. Dendosurono (1989) claimed that individuals' behaviour is the manifestation of their perspective and assessment towards environment comprising of social and physical environment. This perspective and assessment is established over behaviour, knowledge, as well as expectation towards the environment management for their prosperity and quality of life.

The factors of age, education level, wealth, and society's notion toward landslide dealing with the causes and prevention as well as the amount of information of its effects (information input) relate to the society's behaviour towards natural preservation, anxiety, and interest. The behaviour is empowered by the motivation of the society to fulfil their needs. This motivation results in the propensity to ignore natural preservation. Natural preservation can only be maintained by implementing proper land management. Meanwhile, the society's behaviour emerges the possibility of either triggering or preventing the natural degradation, including landslide, to occur. Thus, the expected behaviour in relation with the nature preservation is the behaviour that supports the landslide mitigation.

Hull (1943, in Gredler, 1991) stated that the preservation of organism relies on the human behaviour. Education, poverty, knowledge of landslide, and the amount of information input of landslide would affect the society's behaviour in managing the land susceptible to landslide. The society's behaviour in managing land equipped with a certain amount of knowledge about landslide is expected to lead to mitigation effort. The expected landslide mitigation can be manifested through active participation of all members of the society in the effort of landslide prevention. The landslide prevention based on the capacity of the society was planned, conducted, supervised, and evaluated by the society with the support of disaster management organization. It covered several aspects such as the physical materials and equipments, development organization, and disaster management. The society's participation to cope with landslide can be identified from the land management which is 
theoretically effective and efficient in relation with the landslide mitigation. The purpose of this research was to investigate the effect of educational background, income, land tenure, knowledge, and information input towards the society's attitude in managing the land susceptible to landslide in Pekuncen subdistrict, Banyumas district.

\section{Research Method}

This research was a survey research. Questionnaires were used to collect the data. In this research, the research methodology covered the description of variable and data, data collection, data analysis technique, and analysis results.

\section{Location of Study}

The research area was administratively located in Pekuncen sub-district, Banyumas district. It was situated at $109^{\circ} 01^{\prime} 39^{\prime \prime} \mathrm{E}$ to $109^{\circ} 09^{\prime} 22^{\prime \prime} \mathrm{E}$ and $7^{\circ} 15^{\prime} 25^{\prime \prime} \mathrm{S}$ to $7^{\circ} 24^{\prime} 37^{\prime \prime}$ $\mathrm{S}$ or situated between $282.831 \mathrm{Em}$ to 294.317 Em and 9.180.805 Nm to 9.193.344 Nm on the coordinate of UTM. The total area of Pekuncen sub-district is $8.277,69$ ha and consists of 16 villages including Cibangkong, Petahunan, Semedo, Cikawung, Karangklesem, Candinegara, Cikembulan, Tumiyang, Glempang, Pekuncen, PasiramanLor, PasiramanKidul, Banjaranyar, Karangkemiri, Kranggan, and Krajan.

\section{Variable}

The variable of this research consisted of two variables divided into independent $(\mathrm{X})$ and dependent variable (Y). Independent variable (X) consisted of: education $\left(\mathrm{X}_{1}\right)$, income $\left(\mathrm{X}_{2}\right)$, land ownership $\left(\mathrm{X}_{3}\right)$, knowledge $\left(\mathrm{X}_{4}\right)$, and information input $\left(\mathrm{X}_{5}\right)$. The dependent variable (Y) was the society's behaviour in managing the land.

\section{Data}

The data used in this research consisted of the primary and secondary data. Primary data comprised of education, income, land tenure, knowledge, information input, and the society's behaviour in managing the land. Meanwhile, the land susceptibility to the landslide was classified into classes which were employed as the secondary data.

\section{Data Collection}

In gathering the data from the population and sample, the stratified random sampling was applied as the sampling technique. The respondents of this research consisted of the heads of family in the research area. The technique was preferred to compare the society's behaviour in managing the area susceptible to landslide in accordance to the class of susceptibility. Therefore, the susceptibility class was employed as the strata. The parameter of each susceptibility class was not in line with the administration parameter which was used to assess land use unit. Hence, the number of population could not be certainly determined on each class of land susceptibility. The total sample of this research was 120 heads of family. Therefore, each class consisted of 40 heads of family as the respondents. The number of samples were based on statistical analysis techniques which were employed. Statistical analysis applied in this research was a parametric statistic which required more than 30 samples for each class (Singarimbun and Effendi, 1995). The number and location of each land susceptibility class is presented in table 1 .

Table 1. The number of respondents from each class.

\begin{tabular}{lllc}
\hline No & $\begin{array}{c}\text { Susceptibility } \\
\text { class }\end{array}$ & \multicolumn{1}{c}{ Location } & Sample \\
\hline 1 & Low & Ds. Tumiyang & 40 \\
2 & susceptibility & Ds. Krajan dan & 40 \\
3 & Medium & Petahuan & 40 \\
& susceptibility & Ds. Cibangkong & \\
& High & dan Karangkemiri & \\
& susceptibility & & 120
\end{tabular}

\section{Collection and Analysis of Data}

The data of society's behaviour in managing the area susceptible to landslide were obtained from the interviews with the respondents. 
The interviews were conducted to try out the instruments and collect the research data. The interviews were carried out by the researchers and some students. In prior to the field study and the interviews, the students had been trained and instructed for the orientation. The training material focused on the explanation of the content to provide them similar perception. Collected data consisted of educational background(success year), knowledge of landslide, information input, income, land tenure, and the society's behaviour in managing the area susceptible to landslide.

Data of landslide knowledge, information input, and the society's behaviour in managing the area susceptible to landslide were analysed using the frequency table by dividing them into three categories as developed by Sutrijat (1999). The three categories were low, medium, and high. The categorization was based on the score of each variable. The total score of each variable was dissimilar due to different numbers of question. Therefore, it was converted into the range of 100 to standardize the score.

The data of income was used as the parameter to classify the society's economic class by employing the minimal wage of Banyumas regency in 2011 which was Rp.795,000,per month. The data of land tenure used in this research was based on the width of the managed area both the personal property and hire from other owners or the government ( agricultural tenancy). Data of land tenure was classified into three categories of small, medium, and vast land.

\section{Data Analysis}

Data analysis to manifest the objectives was conducted by using parametric statistic technique. Parametric statistic was employed since ratio of data scale and data of dependent variable were normal and homogenous. For that reason, multiregression formula presented on pattern 1 was employed to each predictor (Sugiyono, 2010). The formula was implemented on five predictors of education $\left(\mathrm{X}_{1}\right)$, income which was the amount of rupiahs earned in a month in the form of wage or salary $\left(\mathrm{X}_{2}\right)$, land tenure that was the width of managed land $\left(\mathrm{X}_{3}\right)$, knowledge that was the total score of knowledge variable achieved by the respondents $\left(\mathrm{X}_{4}\right)$, and information input that was the total score of information input variable received by the respondents $\left(\mathrm{X}_{5}\right)$ towards their behaviour of land management. The total scores of the respondents (Y) in land management were calculated with the formula as follows.

$Y=a+b_{1} X_{1}+b_{2} X_{2}+b_{3} X_{3}+b_{4} X_{4}+b_{5} X_{5}$

There were four assumption tests comprising of multicollinearity, autocoreelation, normality, and homoscedasticity to validate the equation of multiregression. The multiregression assessed the relationship among independent variables. Multicollinearity assumption test used the tolerable limit of VIT score between 1-4. Autocorelation assumption test used the tolerable limit of Durbin-watson score between 1-3. Normality assumption test was used if the probability plot graphic turned into a linear pattern. Homoscedasticity assumption test was applied if the scatter plot did not turn into any patterns.

\section{Research Result}

\section{The Characteristics of the society}

The members of the society were mostly in the category of productive age. For this reason, they would do their efforts to manage their land. The management of land covered the effort to fulfil their daily needs such as housing and other needs. It was also a reflection of their behaviour towards their environment. Olli et al. (2001) stated that there was a strong correlation between age and behaviour towards the environmental awareness. The members of the society were dominated by people aged 30-50 years, or approximately $57.50 \%$ of total members. 
Education level was based on their success year which is the duration that the respondents spent for their study in the formal institution, instead of based on their last certificate. Educational background influences the behaviour of a society. Dimyanti and Mudjiono (2009), Abraham (1991), Inkeles and Smith (1976) reaffirmed that education is a strong and consistent predictor of individual's behaviour, value, and attitude towards the future. The education level of the society was low indicated by the finding that $58.33 \%$ of the respondents merely spent 6 (six) years or less for formal education. In addition, the respondents who obtained 9 (nine) years formal education were approximately $18.33 \%$, while the rest of $4.17 \%$ were college graduates. However, the low educational background would affect people behaviour in managing land in the research area.

The respondents who were in the category of low economic class were $34.17 \%$. Dimyanti and Mudjiono (2009), Abraham (1991), Inkeles and Smith (1976) stated that social pressure in the form of family economic condition contributed in the development of individual's attitude and behaviour. Subsequently, the behaviour will determine individual's action in the future. Individual from a low economic class has a propensity to perceive natural resources as a means to survive. This argument was supported by Hull (1943) in Gredler (1992) that behaviour is aimed to keep an organism alive.

Society's knowledge about landslide in each susceptibility class can be categorized as high. Krech et al. (1963) argued that humans' behaviour was determined by their knowledge of a certain object. Dendosurono (1989) stated that humans' behaviour was constructed by their view and evaluation towards their environment. The view and evaluation were based on the received knowledge. Society possessing a broad knowledge will have a better view and evaluation towards the environment which is reflected from their behaviours.

The level of information input obtained by the society from both print and electronic media as well as from the regional government or non-government organization was considered as low of $79.17 \%$. Information input is a communication process working for altering knowledge, attitudeorbehaviour of the message receiver (Mulyana, 2008). Rogers et al. (1971) stated that the effects of communication process involved the knowledge development and the change of behaviour of the message receiver. Information input regarding with landslide was expected to change the attitude and behaviour of the society in managing the land.

The behaviour in managing land is in line with human activities to fulfil their needs (Hull, 1943 in Gredler, 1992). The respondents' behaviours in accordance with the susceptibility class were diverse. Based on the behaviour in managing the land, the amount people of the low susceptibility class, the medium susceptibility class, the high susceptibility class who had high category of behaviour were, respectively, $5 \%, 12.5 \%$, and $12.5 \%$.

The Effect of Education, Income, Land tenure, Knowledge, and Information Input on the Society's Behaviour in Managing The Land

The effect of education, income, land tenure, knowledge, and information input was dissimilar on each susceptibility class. The significance of the effect of those variables can be examined from the predictors' coefficient. The higher predictors' coefficient would lead to the stronger effect collectively or individually. Table 2 presents the coefficient of each predictor. 
Table 2. The value of coefficient of each predictor.

\begin{tabular}{|c|c|c|c|c|c|c|c|c|c|c|}
\hline \multirow{2}{*}{ No } & \multirow{2}{*}{ Predictor } & \multicolumn{3}{|c|}{ Low Susceptibility } & \multicolumn{3}{|c|}{ Medium Susceptibility } & \multicolumn{3}{|c|}{ High Susceptibility } \\
\hline & & B & $\mathbf{t}$ & Sig. & B & $\mathbf{T}$ & Sig. & b & $\mathbf{T}$ & Sig. \\
\hline 1 & Education & 0,234 & 0,908 & 0,370 & 0,934 & 1,655 & 0,105 & 0,412 & 0,936 & 0,356 \\
\hline 2 & Income & 0,001 & 0,318 & 0,752 & 0,014 & 2,762 & 0,010 & 0,005 & 1,647 & 0,109 \\
\hline 3 & Land tenure & 0,036 & 1,082 & 0,287 & 0,024 & 0,838 & 0,327 & 0,001 & 1,574 & 0,125 \\
\hline 4 & Knowledge & 0,194 & 1,107 & 0,276 & 0,241 & 0,887 & 0,382 & 0,158 & 0,535 & 0,596 \\
\hline 5 & Information input & 1,715 & 7,308 & 0,000 & 0,466 & 1,562 & 0,114 & 1,098 & 2,112 & 0,042 \\
\hline \multicolumn{2}{|c|}{$\begin{array}{l}\text { Coefficient of Determination } \\
\left(\mathrm{R}^{2}\right)\end{array}$} & \multicolumn{3}{|c|}{$67,1 \%$} & \multicolumn{3}{|c|}{$69,9 \%$} & \multicolumn{3}{|c|}{$38,2 \%$} \\
\hline \multicolumn{2}{|c|}{ t-value } & \multicolumn{3}{|c|}{5,631} & \multicolumn{3}{|c|}{3,855} & \multicolumn{3}{|c|}{4,038} \\
\hline \multicolumn{2}{|c|}{ Significance } & \multicolumn{3}{|c|}{0,000} & \multicolumn{3}{|c|}{0,000} & \multicolumn{3}{|c|}{0,000} \\
\hline
\end{tabular}

Source: Statistic result test.

According to Table 2, it can be seen that the variable of education, income, land tenure, knowledge, and information input collectively influenced the society's behaviour in managing land in the low, medium, or high susceptibility class, significantly. In the mediumsusceptibility class, the determination co-efficient value (R) was $69.9 \%$, which was higher that the low and high class. Hence, the effect of five variables on the society's behaviour in managing land of medium class was higher than the low and high susceptibility class.

The effect of education, income, land tenure, knowledge, and information input did not individually influence the society's behaviour in managing land. . In the high susceptibility class area, independent variable which significantly influenced the society's behaviour was the information input. Meanwhile, the most influential independent variable which significantly affected the society's behaviour in the medium susceptibility class was the income. In the low susceptibility class, information input was the only significant factor that affected the society's behaviour in managing land.

According to Table 2, the amount of information input was the predictor which strongly determined the society's behaviour in managing land (Mulyana, 2008 and Abraham, 1991). The result of this research was similar to Sutrijat (1999), that there was a positive relationship between knowledge of ecosystem and agriculture, information input regarding with agriculture, and education level of a society in relation with land management.

\section{Conclusion}

The residents of Pekuncen sub-district, in general, realized that they lived in an area susceptible to landslide. However, the economic problems became the main reason for the society to keep harnessing the area to fulfil their needs. To prevent any disaster, it was intensely banned to conduct any slope cutting in the area classified as high-susceptible to landslide for any kind of land use. Yet, the fact showed that the residents insisted in carrying out slope cutting as well as slope pilling for housing and farming.

The variables of educational background, income, land tenure, knowledge, and information input that significantly affected the society's behaviour in managing land were classified into low, medium, and high class. In the area of medium class, it was found out that determination coefficient value $\left(\mathrm{R}^{2}\right)$ was $69.9 \%$. This value was higher in compared with both of the low and high class. It indicated that the independent variable of medium class significantly affected the society's behaviour in managing the area susceptible to landslide. The quantity of information about the effect of landslide received by the society was also an influential factor which significantly increased the society's awareness in the area susceptible to landslide, both the area in low and high class. 


\section{References}

Abraham, M.F., 1991. Modernisasi di Dunia Ketiga. Suatu Teori Umum Pembangunan, Tiara Wacana Yogya, Yogyakarta.

Dimyanti dan Mudjiono, 2009. Belajar dan Pembelajaran, Rineka Cipta, Jakarta.

Dendosurono, P., 1989. Pemikiran tentang Pelaksanaan Pendidikan Kelautan di Indonesia, dalam Konferensi dan Seminar Nasional 1. Badan Kerjasama Pengelolaan PKLH antar IKIP dan FKIP se Indonesia, IKIP Jakarta, Jakarta.

Enemark, S., 2007. Land Management in Support of The Global Agenda, V Internasional Congress Geomatica 2007: "Geomatics for The Development” 12 - 17 February 2007, Havana, Cuba.

Gredler, M.E.B., 1991. Belajar dan Membelajarkan, Rajawali, Jakarta.

Inkeles, A., and Smith, D.H., 1976. Becoming Modern: Individual Change in Six Developing Countries, President and Fellows, Harvad Collage, Cambridge.

James, L., Gibson, John, M., Ivancevich, James, H., and Donnelly, 1996. Organisasi (Perilaku, Struktur, Proses), Edisi 8, Binarupa Aksara, Jakarta.

Krech, David, Crutchfield, Richard, S., and Ballachey, E.L., 1972. Individual in Society, McGraw Hill, New York.

Marfai, M.A., 2009. Pendidikan untuk Mitigasi Bencana di Indonesia, Paper presented in National Seminar 26 December 2009, Program of Geography Education, Universitas Muhammadiyah Purwokerto, Purwokerto.

Mulyana, D., 2008. Ilmu Komunikasi Suatu Pengantar, Remaja Rosdakarya, Bandung.

Olli, E., Gunnar, G., and Dagwollebaek, 2001. Correlates Of Environmental Behaviors Bringing Back Social Context, Environment And Behavior; Vol. 33; No. 2, March 2001, pp 181208 .

Rogers, Everett, M., Shoemaker, F., and Floyd, 1971. Communication of Innovations, The Free Press, New York.

Singarimbun M., dan Effendi S., 1995. Metode Penelitian Survei, PT Pustaka LP3ES Indonesia, Jakarta.

Stubbs, and Jeffry, 1996. Megacity Management in The Asian and Pacific Region, The Asian Development Bank, Manila.

Stephen, P.R., and Timothy, A.J., 2008. Perilaku Organisasi (Organizational Behavior), Salemba Empat, Jakarta.

Sugiyono, 2010. Statistika untuk Penelitian, Alfabeta, Bandung.

Sutrijat, S., 1999. Perilaku Petani Dalam Pengelolaan Lahan Pertanian, PT Pustaka Sawab Abadi, Jakarta.

Tejoyowono, 1990. Kreteria Penataan Ruang dan Implementasinya untuk Keterlanjutan Penggunaan Lahan bermaslahat, soil.faperta.ugm.ac.id/tj/1981/1990\%-20krit.pdf, Accessed on 18 February 2010.

Uyanto, S., S., 2009. Pedoman Analisis Data dengan SPSS, Graha Ilmu, Yogyakarta. 